\title{
Pericardial Teratoma
}

National Cancer Institute

\section{Source}

National Cancer Institute. Pericardial Teratoma. NCI Thesaurus. Code C147103.

A teratoma that arises within the pericardium. 